\title{
Deflationism, Rationalism, and Anti-Rationalism: Three Views of Superego Morality
}

\author{
Ching Wa Wong \\ Department of Applied Social Sciences, Hong Kong Polytechnic University, Hong Kong, China \\ Email: sscwwong@polyu.edu.hk \\ Received 26 May 2015; accepted 9 August 2015; published 14 August 2015 \\ Copyright (C) 2015 by author and Scientific Research Publishing Inc. \\ This work is licensed under the Creative Commons Attribution International License (CC BY). \\ http://creativecommons.org/licenses/by/4.0/

(c) (i) Open Access

\begin{abstract}
Philosophers of psychoanalysis have for years been debating over Freud's criticism of morality as a sheer product of irrationality originated in our superego development. In this paper I shall consider three views on Freud's moral psychology, which I call the "deflationist", the "rationalist", and the "anti-rationalist" view. I argue that both the deflationist and the rationalist view are untenable, as they fail to distinguish among different senses of irrationality that we can attribute to morality. By contrast, I shall develop and defend an anti-rationalist view, to the effect that an inherently irrational superego is no threat to morality's place in human life, as long as it's capable of making us experience an integrated form of life. And as this desired interaction does not always come easily, we can naturally see the point of introducing psychoanalysis to our lives.
\end{abstract}

\section{Keywords}

Freud, Klein, Moral Psychology, Psychoanalysis, the Superego

\section{Introduction: Psychoanalysis and Moral Philosophy}

Moral philosophers' interest in Freudian theory came very late in the twentieth century, and it was not until the early 1980s that systematic discussions of its relationship with moral philosophy began to emerge in the Englishspeaking world. Since then, a host of philosophers have produced important and interesting works on the subject following the lead of Richard Wollheim. ${ }^{1}$ However, their assessments of Freud's moral thinking differ, and there is so far no fully developed moral psychology to which the predicate "psychoanalytic" can be applied.

\footnotetext{
${ }^{1}$ Wollheim (1984); Lear (1992); Scheffler (1992); Cavell (1993); Gardner (1993); Wollheim (1993); Deigh (1996); Cottingham (1998); Lear (1998); Wollheim (1999); Lear (2005); Velleman (2006). A common feature of almost all the writers named above is their tendency to affirm the contributions of Freud's theory to the understanding of mind and morality, but independently of its claim to be a science. So we may duly regard their approach to psychoanalysis as founded on the extension of commonsense psychology. For a statement of this approach, see Gardner (1995).
} 
The present work is an attempt to continue this project of integrating psychoanalysis with moral philosophy, and with a special emphasis on the normative implications of Freudian theory. Specifically, I shall discuss whether the hypothesis of the superego is compatible with a positive view of morality as contributive to the good life. Notably, some philosophers may be inclined to follow Freud's negative view of morality, which suggests a version of moral deflationism, to the effect that morality need be discarded because it is a sheer product of irrationality that we inherit from our superego development. ${ }^{2}$ Some others, however, are inclined to save morality from Freud's attacks by adopting a rationalist view of superego morality, according to which he has not been successful in showing that the superego is essentially irrational. I believe, however, that the debate between the two sides is wrongheaded, as both parties fail to distinguish among different senses of irrationality that we can attribute to morality, and so they overlook the possibility of an inherently irrational superego's contribution to the good life. Accordingly, I will develop and defend an anti-rationalist view on the issue, which sees morality as both originating in phantasy, and also causally productive of an integrated life in some favourable situations. I argue, in effect, that the irrationality of a benign superego is no threat to the place of morality in human life. Here, as elsewhere in the philosophy of psychoanalysis, Wollheim's work remains the source of inspiration for our discussion. With his version of moral deflationism, I will start my discussion.

\section{The Deflationist View: Wollheim's Critique of Morality}

By now, Wollheim's contribution to the understanding of Freudian moral psychology can hardly be disputed. But it remains controversial how we are to evaluate his psychoanalytic critique of morality famously put forward in The Thread of Life (Wollheim, 1984: ch.7). Reconstructing Freud's theory of the superego in the light of Klein's work on phantasy, he casts serious doubts on the commonsense conception of morality as a system of obligations; and so he argues that we need a wider and revised conception of morality, which comprises not only the matter of "obligation", but also of "value" (ibid., p. 221). Although largely sympathetic to it, I think there is room for his account to be converted to a more positive view of commonsense morality. In this section, I will highlight some difficulties with Wollheim's deflationist reading of Freud, and explain why it is in need of further clarifications.

Wollheim endorses Freud's hypothesis that the superego is the source of adult moral motivation, but he modifies it by introducing the Kleinian account of phantasy (cf. Isaacs, 1952; Klein, 1959). As we know, Freud's theory says that the superego is modelled on a certain parental figure, which the child both loves, hates, and fears. In consequence of the child's fear of punishment and longing for parental love, a psychic structure is formed as the representative of the parent. Metaphorically put, a part of his ego is split off, and this becomes the superego which watches, commands, and controls the child from within, making the ego an object instead of a subject (Freud, 1933: pp. 58, 61-62). The superego then continues to represent the claims of morality through the internalization of parental authority. Now Wollheim argues, appealing to Klein's theory, that this mechanism of "introjection" or "internalization" has powerful emotional effects on the person, because it is embodied in a phantasy of physically incorporating some object into the child's body. ${ }^{3}$ When faced with a certain aggressive object, the child is inclined to phantasize devouring and destroying it. Thereafter, the devoured object does not disappear in phantasy; rather, it is felt to be residing in his body, watching and controlling him in a way that induces him to conform to certain parental values (Wollheim, 1993: pp. 52-53; Freud, 1933: p. 163). As a result, the child's moral character is formed on the model of the internal parental figure. When grown up, the person will be unable to resist the orders of the superego, as it is no more and no less than a powerful phantasy that has been haunting him since long.

On a closer reading, the thrust of Wollheim's argument is that there is an infantile condition of the mind, a primordial way of thinking, which rationality never leaves totally behind. Specifically, he holds that the mind

\footnotetext{
${ }^{2}$ Following Scheffler (1992: pp. 65-66), I takes a view of morality as “deflationary” if it holds that our commonsense conception of morality is erroneous and need be revised. Accordingly, the task for a moral deflationist is to explain why people tend to accept, say, a Kantian view of morality as rationally binding, when in fact its so-called authority is just a by-product of either desire or emotion. By this light, Freud's moral psychology may be interpreted as deflationary, as it implies that morality's impact on our motivation is all due to some mixtures of desires and emotions originated in our Oedipus complex, plus the reinforcement by social and economic necessities. For his account of the superego, see Freud (1933: pp. 58-65).

${ }^{3}$ On Klein's account, the two basic mechanisms by which the infant deals with its object-relations are "projection” and "introjections”. Projection involves the phantasy of expelling something (e.g., the infant's hatred) out of the body. Introjection, by contrast, is "the mental activity... by which, in his phantasy, he takes into himself everything he perceives in the outside world” (Klein, 1936: p. 291). Klein (1959: p. 250) does not often use the word "internalization”, but her definition of introjection amounts to "experiencing the external as part of the inner life".
} 
has a tendency to gratify a desire by invoking the image of some object, in which case the desire degenerates into a wish (Wollheim, 1984: pp. 90-91; 1974: p.47). It is at this point that we can see how phantasy enters into the thought of a person. Phantasy, as Wollheim sees it, is an "iconic", imagistic, and non-propositional form of imagination, which works in conjunction with the child's "archaic theory of the mind", to the effect that there is no difference between imagination and reality, and that his thoughts are "omnipotent" (ibid., pp. 63-64; cf. also, Freud, 1909: pp. 233-235; 1912-1913: pp. 85-90). Because the child cannot distinguish between his mental images and the objects that they represent, he simply mistakes his imagined oral attacks on the parent as real happenings. Not only this. His subsequent thought of having an internal object inside his body is also a phantasy, and it affectively modifies him through the production of fear and guilt. The only way to shun these emotions, as it were, is to conform to the values that he believes his parent has. The resulting moral motivation is no exercise of autonomy as Kant sees it. It is simply produced by the person's self-induced guilt, and is a price that he has to exact because of his infantile past (Wollheim, 1984: pp. 204-205).

Wollheim's critique of morality, thus, urges us to subvert the authority of morality by pointing to its irrational and infantile origins. However, it seems unclear if he is attacking morality simply because it is irrational, or because it is irrational in some more specific sense. No doubt he is dissatisfied with the Kantian conception of morality because it is detrimental to the individual's search for happiness. As a Millian naturalist, his alternative is a form of life which gives us as many opportunities as possible to experiment on our conceptions of happiness, a way of living which takes value and not obligation as its model. But Wollheim later also argues that value is the projection of one's sense of goodness, a way of seeing the world as good caused by one's phantasy of being in union with the good object (ibid., pp. 221-224). So how come he criticizes morality for its being irrational?

To answer the question, make a distinction between what I call formal irrationality and psychic irrationality. In my sense of the words, a person is formally irrational if his beliefs, desires, emotive attitudes, and behaviour are interconnected in an inherently inconsistent pattern. ${ }^{4}$ This irrational form is found, for example, in a person's akratic actions, in self-deception, or in a life that vacillates between extremely incompatible values. In either case, the person's life, or a piece of it, risks being fragmentized, and this he cannot give an coherent account of. Different from that, psychic irrationality is all about the psychological states, processes, and activities which explain why a person is formally irrational-it is the stuff on which the irrational form is imposed. In the context of Freudian theory, let us assume that psychic irrationality refers to the total system of unconscious mental states, processes, and mental activities, as are exemplified by our wishes, phantasies, and various defence mechanisms. ${ }^{5}$ So we may say that morality exhibits formal irrationality to the extent that we live an inconsistent pattern of life under its reign. We set ourselves the goal of gaining happiness, but eventually end up following the rule of the superego, which makes happiness even more distant from us. But if asked how this formal irrationality comes about, Wollheim would appeal to our primitive phantasies, which constitutes the superego. These phantasies, in effect, are the materials on which the formal irrationality of morality is built; but they may not be objectionable in themselves. What is objectionable is the inconsistency, disunity, or disintegration of life that results as they develop into a narrative of the harsh superego. ${ }^{6}$

The distinction between formal and psychic irrationality may not appear significant as long as we assume that they converge in the case of neurotic personality. But then it is important to note that the two sorts of irrationality do not always co-exist. One possibility is that when phantasies are dominant, a person still lives happily and sees his action as conforming to the will of a loving mother. He desires what such a good parent would desire; and

\footnotetext{
${ }^{4}$ Cp. Gardner (1993: p. 3): "Irrational phenomena have the following form: a person exhibits irrationality when he does not, or could notwithout altering himself in a way that would tend towards the eradication of the phenomenon in question - think about himself in a way that would both make adequate sense of his own thought and/or action, and at the same time avoid exhibiting incompleteness, incoherence, inconsistency, lapse into unintelligibility, or some other defect of a kind to signify, in suitably broad sense, self-contradiction.” This view of irrationality is purely formal, as it does not tell us what actions and thoughts actually count as irrational, but only defines irrationality in terms of a defective condition of self-knowledge.

${ }^{5}$ Philosophers normally understand this system of irrationality as in contradistinction with belief-desire psychology. Gardner (1993), for example, speaks of wish and phantasy as "pre-propositional” mental states. Lear (1995) agrees with Gardner's thesis of the heterogeneity of the mental, but denies that those irrational items like wish and phantasy are vehicles of meaning. He argues that they do not contain any mental contents, but are mental activities (on a par with repression and other defence mechanisms) which disrupt the propositional network of belief and desire.

${ }^{6} \mathrm{My}$ distinction between psychic and formal irrationality has parallels with the traditional distinction between matter and form. Suppose, for the sake of argument, there is such a thing as "the irrational system of morality". On the traditional account, its existence must depend on its essential form and its underlying materials. The underlying materials I argue to be psychical irrationality. But just by possessing these materials, we will not form the irrational system; it is only when the materials are connected with each other in a particular pattern that we can see the irrational form of the system.
} 
when acting on her values, he feels not the threat of punishment, but the satisfaction of being like her. This possibility is acknowledged in Wollheim's argument for a happier interpretation of morality, according to which the superego can develop into something more positive-an ego ideal with which the person identifies, and which produces in him a sense of goodness in virtue of the force of love. ${ }^{7}$ So it seems to me important to ask of Wollheim: Do we find morality objectionable because it is a product of phantasy? Or because it often induces some inconsistent patterns of life which a person cannot comprehend? With the distinction between formal and psychical irrationality, he cannot be taken to mean that morality is objectionable simply because it is a product of phantasy. The real issue here is under what conditions a person's psychic irrationality will contribute to a disintegrated form of life, and under what conditions it will not. I shall return to these questions in section IV below.

\section{The Rationalist View: Scheffler and Velleman}

Leaving for a while Wollheim's deflationist view, it may be suggested that there is a more straightforward way to rescue the authority of morality, and it is that we deny that psychic irrationality is an essential component of our moral motivation. The idea, as is given in Scheffler (1992: chs.4 \& 5) and Velleman (2006: ch.6), is that Freud's writings have the materials needed for reconstructing the conception of a rational superego. Their arguments aim to show that a person with a healthy superego should possess some rational capacities to discriminate true from false values, and those capacities are independent of the infantile desires to shun punishment and win love. In other words, a genuinely authoritative superego is not psychically irrational, as its existence is not parasitic on the kinds of archaic desires and phantasies we find in infancy and neurosis; and so there is no further question how it constitutes the formal irrationality of morality. I shall in this section spend some time discussing the strengths of these rationalist arguments. But I will also argue that they have not been successful at all, and in places they have fatally overlooked the damaging character of Freud's account of human moral self-misrepresentation.

Scheffler's argument begins with the observation that the superego's commands, as Freud sees it, "are not guidelines for the satisfaction of some sentiment we feel towards other people", but "have precisely the function of overriding sentiments" comparable to the Kantian sense of duty, which is distinct from desire-based and sympathy-based motivations (1992: 83-84). But how then do we know if these overriding sentiments are not also a product of irrationality? Here, Scheffler makes an interesting point that Freud's description of the conscience is unduly modelled on pathological cases (ibid., p. 85). And so he attempts to provide a non-pathological version of it by considering whether a person can acquire rational grounds for his moral conduct through the internalization of a certain ideal, which "supplies the psychological background against which considerations of certain types are perceived as in themselves providing reasons for actions" (ibid., p. 90). This, his argues, is made possible by Freud's view that the superego consists in part in the existence of an "ego-ideal", a benign and not punitive internal parental figure which serves a more positive role in a person's moral development than that of the punitive superego (ibid., p. 88-90). ${ }^{8}$ Elaborating on this final point, Velleman further argues that there is in fact one objective and internalized value that most people share as they develop their ego-ideals. This value is that of our respect to other human persons as autonomous beings, and we internalized this value as we internalized our good parents who loved us unconditionally—we learnt from them what it is to love others without considering our own desires (Velleman, 2006: 154). Across different individuals' superegos, thus, we can see the same ground for affirming the authority of morality, and it is that love obligates all of us to treat persons as persons. Or so it is argued in Velleman's Kantian tone.

\footnotetext{
${ }^{7}$ See Wollheim (1984: p. 219). Literally, “ego-ideal” is defined as “[the] self's conception of how he wishes to be”, inciting thus a sense of shame and not guilt when the wish is not fulfilled (Rycroft, 1995: p. 45).

${ }^{8}$ Recognizing the varieties of interpretations of the ego-ideal concept, Scheffler nonetheless is satisfied by quoting Freud's very early formulation of it in On Narcissism, which describes it as a person's setting up "an ideal in himself by which he measures his actual ego" (Freud 1914: p. 93; emphasis original). And throughout Scheffler’s argument, the term ego-ideal means no more than this. A closer look of Freud's text, however, suggests that he uses this concept mainly to explain how a person can, due to the creation of some phantasized figure, withdraw interests form the world and form some kind of narcissistic self-love. By this light, Meltzer comments on Freud's idea thus: “...the ego-ideal is a rather gentle and encouraging figure, and Freud somehow manipulates the concept of narcissism so that the relation between the self and the ego-ideal begins to be something like a love relationship” (Meltzer, 1998: p. 84). This point, which is not addressed by Scheffler, is eye-catching to the extent that the ego-ideal is originally presented by Freud as having an egoistic character. But in the subsequent expounding of the concept, Klein holds that the loving relationship concerning the ego-ideal can become other-regarding because of the emergence of the depressive position. Still more complicating is the fact that both Freud and Klein treat the ego-ideal as tied up with a person's unstable phantasies, sometimes undermining the person's self-esteem because he has attributed all the goodness to the ego-ideal. The significance of these points will be evident in my discussion of Velleman's argument below.
} 
I do not want to query the point that the ego-ideal concept provides the key to a happy scenario of morality from the psychoanalytic point of view. But since Scheffler and Velleman argue, contra Wollheim, that the ego-ideal embodies values that a person cannot rationally resist, we must ask what makes these values truly moral values, and not just rationalized cultural or familial biases. Are the instructions of a loving ego-ideal still rationally irresistible if they are contingent upon, say, some religious and political attitudes which vary from parent to parent? How can the internalized values be rationally binding if they are always relative to a person's cultural and family background?

A Kantian may reply by saying that it is not culture- or family-specific values that he takes to be grounds for moral obligations. The authoritative considerations that motivate us to act morally must be highly abstract, so that they can be entertained by all persons regardless of their backgrounds. By this light, the internalized value at the core of the truly authoritative superego is likely to be a universal respect for humanity, and this Velleman argues to be embodied in parental love. He writes:

Out of their love for the child, the parents care for him with a wise good will, to which he responds with love. What the child experiences in being loved by his parents, and what he responds to in loving them, is their capacity to anticipate and provide for his needs, often at the expense of their own interests. And this capacity of the parents is nothing other than their practical reason, or practical good sense, by which their immediate self-gratification is subordinated to rational requirements embodied in another person. It's their capacity to take another person as an end. Hence the child's love for his parents doesn't merely project a superficial glow onto them; it registers the genuine value of their reason and good sense-what Kant would call their rational nature, or humanity_as manifested in their loving care. (ibid.; emphasis added)

In this purest version, parental love shows its unconditional character in an attentive attitude towards the child's needs independently of the parent's interest. When internalized, this pure love gives rise to a moral ideal that guides the person's conduct in life. This being the best scenario of parenting that we may hope for, I nonetheless find it very doubtful whether the real-life parents' devoting attitude is as an expression of their capacity to take another person as an end. Put it bluntly, how might I know that my parents loved me because I was $a$ child, and not only because I was their child? How might I tell if their love to me was not an expression of their wishes to be loved by their parents, or if I did not mistakenly perceive their love as unconditional when it was not? Confusions and doubts of these kinds are not enough to falsify the idea that at least some cases of parental love are genuinely unselfish and are grounded in a respect for humanity. But they leave us restless in thinking whether our so-called respect for humanity is not as a rule the product of self-misrepresentation. They show, in effect, that there is always a possibility of our being inauthentic in the judgement of our values.

I presume that the authenticity objection does not bother Velleman, because his reading of Freud suggests that the child will one day come to experience "the awakening of his own critical judgement" (ibid., p. 150), and the reason why he can become disillusioned with parental figures is that he "possesses an evaluative faculty that is independent of the received values preserved in his superego" (ibid., p. 152). Viewing the matter this way, it is as though we can attribute to the mature ego "the capacity for evaluative judgement" (ibid., p. 153), making it discriminative between false and genuine moral values which have got internalized. This, however, begs the question how the capacity for evaluative judgement is developed in the first place. Does the person learn it from his loving relationship with the good parents? Very likely. But we have said that the perception of parental love is prone to all sorts of distortions, and there is no guarantee that a child is not mistaking selfish love for unconditional love. It is no use to argue that pure parental love helps the child to see the essence of humanity, because the condition of its being true is that the loving relationship be perceived rightly in the first place. Or else we may suggest that the person acquires this rational capacity as the ego develops a stronger sense of external reality. But in this case the hypothesis of the ego-ideal is wholly unnecessary.

The authenticity objection may appear only the expression of a general skepticism about human loving relationship. But I think psychoanalytic theory gives us additional reasons why the child's perception of parental love is especially problematic. The idea is that in ordinary loving relationship, if you idealize your lover excessively, disappointment is not something hard to follow. This is so because the lover is for you a lover qua an external object, and this externality warrants the expectation of disappointment. As an external object, the lover cannot be a part of you and appear wholly ideal by you standard. But in the internalization of some parental figure, the child's primary goal is to blur the distinction between the external and the internal, so that he can either control or protect the loved and hated object. As long as the harsh superego, or, in a better scenario, the loving 
ego-ideal, is formed out of this phantasized taking-in of the object, its development remains unbounded by the values actually held by the real parent.

Here we shall meet up with the question why, as grown-up persons, we are still not able to get rid of those phantasies, which characteristically are at odds with our sense of external reality. No doubt their influence should gradually be decreasing, or else we will live our whole lives in a world of imagination. But perhaps their survival value lies in their effectiveness in handling our emotional shocks generated from childhood memories. Consider the following hypothesis of Klein:

The super-ego - the part of the ego that criticizes and controls dangerous impulses, and that Freud placed roughly in the fifth year of childhood-operates, according to my view, much earlier. It is my hypothesis that in the fifth or sixth month of life the baby becomes afraid of the harm his destructive impulses and his greed might do, or might have done, to his beloved objects...He experiences feelings of guilt and the urge to preserve these objects and to make reparation to them for harm done. The anxiety now experienced is of a predominantly depressive nature; and the emotions accompanying it, as well as the defences evolved against them, I recognized as part of normal development, and termed the "depressive position" (Klein, 1959: p. 255).

It should not be thought that the depressive position, marked by the infant's recognition that both the good and the bad object are one and the same person, implies an eradication of phantasies. Depressive anxieties arise exactly because the infant feels as if he has destroyed the mother whom he loved and hated. As a consequence of the anxieties, new reparative phantasies emerge:

If the baby has, in his aggressive phantasies, injured his mother by biting and tearing her up, he may soon build up phantasies that he is putting the bits together again and repairing her (Klein, 1937: p. 308).

Even so, such phantasized solutions to the problem of emotional shocks remain unstable. And it is here that we see the point of the recurrence of early phantasies in adult life: it is the recurrence of the reparative phantasies that motivates us to be good to others, as a result of which our unconscious sense of guilt is attenuated, and the world appears lovable for us. We become capable of fusing with others in love, as though we are playing the part of a good parent, and so "in phantasy we re-create and enjoy the wished-for love and goodness of our parents' (ibid., p. 312). This explains why the phantasy of a loving and supportive ego-ideal is all the more indispensable, especially for those persons who are considerate to others. But in itself, the ego-ideal is no product of rationality, and there is no guarantee that it can always lead the person to see the world in an objective manner.

All I am arguing is this: If the Kantian, the rationalist, arguments of Scheffler and Velleman are to work at all, there need be a way to show that the loving and caring ego-ideal alone can facilitate the rational capacity to see persons as persons. But psychoanalytic theory gives us no clue to how this is possible. It tells us that distorted perceptions of parental love are all too common, because we have so strong a need to idealize, to purify, and to rationalize our imperfect relationships with the parents. Even worse, both the benign ego-ideal and the punitive superego are products of phantasy from a psychoanalytic point of view. Accordingly, the internalization of a loving and caring parental image is not in itself a growth of rationality, though it can provide a desirable condition for such a growth. In any case, the rationalist arguments involve a radical denial of the relevance of psychical irrationality, or of phantasy, to the Freudian and Kleinian conceptions of ego-ideal, which seems to me strained.

\section{Towards an Anti-Rationalist View of Superego Morality}

The possibility of a rational superego being questioned, we should nonetheless not be pessimistic about the place of morality in human life. For the conclusion so far is only that the ego-ideal as a part of the superego is psychically irrational, that it feeds on the person's wishful phantasies, and that it does not in itself form the basis of a rational faculty of moral perception. But why should we believe that genuine moral authority be rational per se? Is it enough that we have a good, benign, other-regarding conscience, which is not rational?

Thus we may say of the rationalist arguments for superego morality as having confused the benignity with the rationality of our moral sense. Even if we are to maintain that in the best scenario, the person can feel the bliss of being loved when acting on his perceived good, this is not to say the internal representation of this loving force is totally free from the force of psychic irrationality. On the other hand, if we consider the ego-ideal as a phanta- 
sized good parent living inside us, encouraging and guiding us to live up to a certain moral ideal, the effect would be that we get a "solution in phantasy" to our initial problem of self-induced anxieties. This does not poses a problem for commonsense morality, because the latter does not presume that our ability to act on our perceived good depends on the ability to understand why we act as such. Good persons, we say, are a rule driven by the force of love to act morally. It is no objection to their motivation that this force of love is originated in their phantasy of being one with the good and loving parent.

On the face of it, it sounds puzzling how we can make a connection between morality and irrationality on one hand, but maintain that morality is as good as it first appears. Consider, however, a recent argument given by Cottingham concerning the role of phantasy in enhancing human creativity and the search for the meaning of life (Cottingham, 2005: ch.4). Cottingham aims to show that Freud's negative view on religion is indeed less damaging than it seems, because what Freud calls the wishful-phantasy of a fatherly and loving God, which underlies our religious belief, is an "illusion" not capable of being proved or disproved (ibid., 66n). Not being obviously false, this illusion is a most natural thing that human beings embrace in religious symbolisms; and they do it as part of their natural quest for spirituality, for moral self-transformation, and for the fullness of life. If it is now objected that the phantasy at the core of religion is an irrational phenomenon, and the holding of it is at odds with scientific reason, Cottingham's reply is that there are some kinds of knowledge not attainable through the use of objective and scientific discourses alone, and can be got only if we also appeal to our emotional awareness embodied in human practice (ibid., pp. 8-13). Is phantasy all that bad if we are concerned with the cultivation of this emotional awareness? Appealing to the works of Carl Jung and Donald Winnicott, Cottingham suggests that phantasy has the beneficial functions of enhancing human creativity, and of developing their emotional awareness necessary for attaining the knowledge in art, in literature, and in religion.

Of course, Cottingham's account allows the possibilities of both a genuine religious faith, which is facilitated by the beneficial functions of phantasy, and also a defensive type of religious belief, which is induced by the fear of death and the need to flee from anxieties. In any case, what the argument shows is that religion is not necessarily bad, even though in the idealized case, it is no less a product of phantasy. Extending this argument to the case of morality, we may also argue that there are genuine as well as defensive internal moral authorities. That some people's moral senses are perpetuated by their fear of some persecutory figures is no proof that others' moral senses are neither benign nor contributive to a good human life. And yet we need not say that the well-formed moral senses are products of rationality. No, they are not. They are, from the Kleinian perspective, to be explained by the recurrence of some phantasies of good parent-child relationship, and in having a moral life we need not understand how those phantasies work. On the other hand, those phantasies oblige us to engage in various loving relationships with others, because it is only by doing so can we integrate with the world and live a truly happy life. In other words, morality owes it authority not to rationality, but to the happiness that it promises us in social context.

Is this too shocking a conclusion, given Freud's famous insistence that we should stick with a scientific Weltanschauung, viz., to be truthful and resistant of the temptation of illusions? ${ }^{9}$ Here I think we have to be careful in considering why Freud is especially fond of promoting an ethic of truthfulness. He promotes it only to the extent that a certain illusion poses a false picture of the world, and is in need of correction. But there are illusions which need not be attacked in this manner. Artistic illusion, for example, is totally "harmless and beneficent", because "it does not seek to be anything but an illusion" (1933: p. 160). It is harmless to the extent that it is a sheer imaginative expression of the artist's instinctual tensions; and though it receives praise from others because of their sympathy, it does not command a false system of beliefs about the external world-it in fact has no overriding hypothesis about the universe at all. So if we are to appreciate some kinds of illusions as harmless and beneficent as such, it must be that they are totally the individual's business, and they provide no theory which misleads the mass through undue rationalization. Cottingham's ideal case of religion is arguably similar to art in this respect, as it aims merely to transform the individual's character through religious practice, and is not theory-based. I see no reason why we cannot have a similar type of moral illusion which, on the one hand, trans-

\footnotetext{
${ }^{9} \mathrm{Cf}$. Freud (1933: p. 182): "Scientific thought is still very young among human beings; there are too many of the great problems which it has not been able to solve. A Weltanschauung erected upon science has, apart from its emphasis on the real external world, mainly negative traits, such as submission to truth and rejection of illusions. Any of our fellow-men who is dissatisfied with this state of things, who calls for more than this for his momentary consolation, may look for it where he can find it. We shall not grudge it him, we cannot help him, but nor can we on this account think differently." Here Freud is no longer concerned with the illusion of religion only; he also deems art and philosophy (of which Marxism is a prominent example) as two other great illusions by contrast with science. But he argues that these two other illusions are less damaging than religion, as their effects on the mass are either null or very limited.
} 
forms the person's life in a postive way, and on the other hand, is not at odds with science because it contains no theory on which the latter can attack.

Most probably, this ideal conception of morality as non-theory-based, and as a harmless expression of the person's phantasy of good parent-child relation, is not something to be found in such moral theories as Kantianism and classical utilitarianism. These moral theories are, to be sure, systems of propositions which a scientific Weltanschauung can criticize on the ground of their theoretical but rationalizing character. ${ }^{10}$ To arrive at an anti-rationalist view of morality that I have been suggesting, will it do if we appeal to virtue-based ethics, or a Millian individualism in which the person is left alone to experiment on his own happiness? It will be far beyond the scope of my essay to provide an answer. But I speculate that the western philosophical tradition has much room for constructing such a psychoanalytic and anti-rationalist conception of morality.

\section{Why Psychoanalytic Theory?}

Two questions left hanging in my argument are: If it is possible that a person lives his life happily and consistently due to the phantasy of a loving ego-ideal, is there still any point to invoke psychoanalytic theory? If conscious knowledge of the superego (or ego-ideal) is not necessary for living a good life, is there any place of Freudian moral psychology in ethics?

These are difficult questions to which I can only attempt some preliminary answers. And instead of answering them in abstract, I shall suggest a few examples of good and bad moral lives which serve to illuminate the subject matter. To start with, think of a lucky person being brought up in moderate parenting. His mother cares about him, but just to the extent that he will not suffer from being stricken by the excesses of hunger and sickness, and she will leave the matter to him whenever he is physically fit for taking a challenge. Gradually, the child grows up in an environment which appears to him just good enough: not only is the external world not a threat to his existence, but he is also proud of his independence, and he feels like respecting others in the way he mother once did to him. Contrast this, then, with a second case where a person's infantile feeding experience leaves a bad mark on him. The mother's milk comes either too late or too soon, making him too frustrated or too dependent, and eventually he becomes envious towards almost everything around him. In cases as simple as these two, we may safely assume that psychoanalytic theory is relevant only in the second kind of cases, in which aggressive phantasies keep pushing the person to experience the world as prosecuting. In cases similar to the first example, there is just no need to remind the person that his attitude is only an expression of some benign phantasies, except for purely intellectual interest.

But perhaps we should not assume this. A lucky person who happens to have been brought up in a good enough family, who also has a positive attitude towards the world, can at most be described as morally innocent. This is so because all the external contingencies he experiences later in life can easily overwhelm the balance of his psyche, and till this point he can have no idea why in the golden past, he did well to others without being disappointed; and yet now the world suddenly appears so strange to him that all the goodness he once saw in the world is now gone. And this is just the image of Mill's moral crisis that Wollheim draws on in propounding his Freudian ethics (Wollheim, 1980: pp. 315-318). Recalling the old distinction I made in section II, we may say this person has been exhibiting psychical irrationality all the while, but it is only when the moral crisis comes about, or when the psychical balance is disturbed, that we observe the phenomenon of formal irrationality. Our proneness to formal irrationality is all too common, given that the good moral sense is having so precarious a foundation in phantasy.

I must say it is at this point that psychoanalytic theory becomes especially relevant. Perhaps commonsense moral psychology is right in holding that a morally innocent person need not be formally irrational, that he need not exhibit any inconsistent pattern of life; but what it cannot explain is how it is possible for such a person to degenerate at the junctions of life. Perhaps it is that the person's new object of love has so surprising a character that he finds it hard to identify it with the beloved child or mother. Or it might be that his living environment has changed so drastically that he is incapable of entertaining any benign phantasy of being loved. In either case, psychoanalysis provides him with new materials for engaging in the process of living. Either it gives him a theory by which he reflects on his past, or it provides him with new projects of phantasy induced by the analyst. But of course, the former will not quite do. As Freud patiently warns us, a person's mere intellectual apprehension of his own mental problems does little to effect any therapeutic changes.

\footnotetext{
${ }^{10}$ This indirectly supports Wollheim's thesis that moral philosophy is largely a product of self-misrepresentation. See Wollheim (1984: pp. 199-200). Remarkably, his conviction is shared by Bernard Williams (1985: ch.10).
} 
If all this is true, maybe there is no need to give psychoanalytic theory a too high place in ethics. Most readers of Freud, philosophers or others, may on this account be only capable of having an intellectual grasp of the connection between phantasy and the good life. This theoretical knowledge does not thereby enable them to know how to manage their phantasies affectively. Perhaps a good enough psychoanalyst can help them in this respect with his therapeutic skills. But a preacher, a teacher, or a good friend can do similar things as well, provided that the idea of psychical irrationality is taken seriously by such a non-professional helper.

\section{Conclusion}

The question of morality's place in life is as old as civilization itself. Psychology, by contrast, has so short a history that many may doubt whether it is capable of characterizing morality exclusively in its own terms. This being so, still we can see the possibility of integrating the studies of psychology and morality, as long as we drop the philosophical presumption of the primacy of rationality in human life, and begin to see that morality's roots in human irrationality are no threat to its place in life. But having said that an irrational but benign superego owes its authority to its contribution to the good life, I tend not to say morality's hold on us is always stable. We are too weak as human persons. And our good moral senses, our benign ego-ideals, can lose their vigour when sick. The living of a good life depends sometimes on the occasional healing of their sickness, which is a matter of psychological change and not an intellectual endeavour. Freud's achievement, thus, lies not so much in advising people to discard morality for the sake of rationality, as in providing a model of irrationality which renders the convergence between morality and happiness possible, and which provides the psychological measures by which their divergence is made good. Taken seriously, he is the greatest enemy not to morality itself, but to those philosophers who unduly elude irrationality and rationalize morality.

\section{References}

Cavell, M. (1993). The Psychoanalytic Mind: From Freud to Philosophy. Cambridge: Harvard University Press.

Cottingham, J. (1998). Philosophy and the Good Life. Cambridge: Cambridge University Press. http://dx.doi.org/10.1017/CBO9780511612237

Cottingham, J. (2005). The Spiritual Dimension: Religion, Philosophy and Human Value. Cambridge: Cambridge University Press. http://dx.doi.org/10.1017/CBO9780511614866

Deigh, J. (1996). The Sources of Moral Agency: Essays in Moral Psychology and Freudian Theory. Cambridge: Cambridge University Press. http://dx.doi.org/10.1017/CBO9780511624636

Freud, S. (1909). Notes upon a Case of Obsessional Neurosis. In J. Strachey et al. (Trans.), The Standard Edition of the Complete Psychological Works of Sigmund Freud, Volume X. London: Hogarth Press.

Freud, S. (1912-1913). Totem and Taboo. In J. Strachey et al. (Trans.), The Standard Edition of the Complete Psychological Works of Sigmund Freud, Volume XIII. London: Hogarth Press.

Freud, S. (1914). On Narcissism: An Introduction. In J. Strachey et al. (Trans.), The Standard Edition of the Complete Psychological Works of Sigmund Freud, Volume XIV. London: Hogarth Press.

Freud, S. (1923). The Ego and the Id. In J. Strachey et al. (Trans.), The Standard Edition of the Complete Psychological Works of Sigmund Freud, Volume XIX. London: Hogarth Press.

Freud, S. (1933). New Introductory Lectures on Psycho-Analysis. In J. Strachey et al. (Trans.), The Standard Edition of the Complete Psychological Works of Sigmund Freud, Volume XXII. London: Hogarth Press.

Gardner, S. (1993). Irrationality and the Philosophy of Psychoanalysis. Cambridge: Cambridge University Press. http://dx.doi.org/10.1017/CBO9780511554599

Gardner, S. (1995). Psychoanalysis, Science, and Commonsense. Philosophy, Psychiatry, and Psychology, 2, 93-113.

Isaacs, S. (1952). The Nature and Function of Phantasy. In J. Riviere (Ed.), Developments in Psychoanalysis (pp. 67-121). London: Hogarth Press.

Klein, M. (1936). Weaning. In M. Klein (Ed.), Love, Guilt and Reparation and Other Works 1921-1945 (pp. 290-305). New York: The Free Press.

Klein, M. (1937). Love, Guilt and Reparation. In M. Klein (Ed.), Love, Guilt and Reparation and Other Works 1921-1945 (pp. 306-343). New York: The Free Press.

Klein M. (1959). Our Adult World and Its Roots in Infancy. In M. Klein (Ed.), Envy and Gratitude and Other Works 1946-1963 (pp. 247-263). New York: The Free Press. http://dx.doi.org/10.1177/001872675901200401 
Lear, J. (1992). Love and Its Place in Nature: A Philosophical Interpretation of Freudian Psychoanalysis. London: Faber \& Faber.

Lear, J. (1995). The Heterogeneity of the Mental. Mind, 104, 863-879. http://dx.doi.org/10.1093/mind/104.416.863

Lear, J. (1998). Open Minded: Working Out the Logic of the Soul. London: Harvard University Press.

Lear, J. (2005). Freud. London: Routledge.

Meltzer, D. (1998). The Kleinian Development. London: Karnac Books.

Rycroft, C. (1995). A Critical Dictionary of Psychoanalysis. London: Penguin Books.

Scheffler, S. (1992). Human Morality. New York: Oxford University Press.

Velleman J. (2006). Self to Self: Selected Essays. Cambridge: Cambridge University Press.

Williams, B. (1985). Ethics and the Limits of Philosophy. Cambridge, MA: Harvard University Press.

Wollheim, R. (1979). Wish-Fulfilment. In R. Harrison (Ed.), Rational Action (pp. 47-60). Cambridge: Cambridge University Press.

Wollheim, R. (1980). On Persons and Their Lives. In A. Rorty (Ed.), Explaining Emotions (pp. 299-321). London: University of California Press.

Wollheim, R. (1984). The Thread of Life. Cambridge: Cambridge University Press.

Wollheim, R. (1993). The Mind and Its Depth. Cambridge: Harvard University Press.

Wollheim, R. (1999). On the Emotions. New Haven, London: Yale University Press. 